\title{
Bonda i storytelling
}

\section{Michał Larek}

\section{Szukając wiedzy operacyjnej}

Kilka lat temu przeszedłem na drugą stronę barykady i zacząłem pisać książki kryminalne. Dzisiaj uprzytamniam sobie coraz mocniej, że to był gwałtowny punkt zwrotny w mojej biografii literaturoznawcy.

\section{Dlaczego?}

Będę szczery. Chcąc tworzyć popularne opowieści, czyli takie, które adresowane są do szerokiej publiczności, musiałem przeformatować swój umysł. Musiałem wyciszyć w sobie wewnętrznego krytyka czy wręcz „wewnętrznego badacza”, który bez przerwy podszeptywał mi, że czegoś nie wolno napisać, bo jest zbyt mało ambitne. Szybko okazało się, że to, czego nie toleruje akademik, uwielbia czytelnik. Niby nic zaskakującego, ale ta rozbieżność w zakresie gustów miała jedną ważką konsekwencję. W tekstach kolegów po fachu nie mogłem znaleźć wiedzy - bardzo potrzebnej! - którą mógłbym zastosować, projektując kolejne angażujące fabuły. Nawet formaliści czy strukturaliści nie byli tu specjalnie inspirujący. Ową poszukiwaną wiedzę nazwałbym wiedzą operacyjną.

Musiałem więc zmienić branżę i zwrócić się do filmowców, a konkretnie do ekspertów od scenopisarstwa, którzy piszą barwnym językiem skrypty będące czymś w rodzaju poetyki stosowanej.

Były to bardzo owocne, szalenie motywujące korepetycje. Między innymi dlatego, że wiedza dotycząca budowy opowieści została odpowiednio skorelowana z wiedzą o mechanice oddziaływania opowieści na odbiorcę. Jak wiemy, kategoria czytelnika (rozumianego jako konkretny uczestnik aktu komunikacji) jest dla badacza zazwyczaj drugo- albo nawet trzeciorzędna.

Kiedy zacząłem testować ową wiedzę, już jako autor zapoznający się z konkretną i jednostkową recepcją swoich kryminałów, stwierdziłem, że jest ona całkiem skuteczna, że naprawdę działa.

No i połknąłem bakcyla. Pisanie, które w istotnej mierze sprowadza się do operowania na emocjach czytelników, wciągnęło mnie, stało się pasją, pracą na drugim etacie.

Mniej więcej w tym samym czasie zacząłem prowadzić warsztaty z kreatywnego pisania na szerszą skalę, musiałem więc sporządzić listę przydatnych tekstów dla swoich uczniów. 
Ze smutkiem stwierdziłem, że nie ma na niej pozycji literaturoznawców - wyjątkiem są skrypty Joanny Wryczy-Bekier (która jednakowoż nie prowadzi działalności naukowej). Okazało się bowiem, że z punktu widzenia pisarza oraz szkoleniowca uniwersytecka nauka o literaturze jawi się jako działalność autoteliczna, jako szalenie wyrafinowana, ale i, co tu kryć, bezproduktywna gra znakomicie wykształconych, nierzadko naprawdę wybitnych umysłów.

Kto zatem pojawił się na tej liście? Scenarzyści i reżyserzy, spece od marketingu, badacze „business storytelling”, storytellerzy, a nawet antropolodzy (chociażby Joseph Campbell), czyli, najogólniej rzecz ujmując, przeróżnej maści eksperci zajmujący się narracją jako narzędziem wpływu.

Wśród nich znalazła się Katarzyna Bonda, pisarka kryminalna, twórczyni Maszyny do pisania oraz autorka podręcznika, który pojawił się na rynku w 2015 roku, tuż po wydaniu Pochłaniacza, powieści przełomowej dla jej prozatorskiej kariery. Co wymowne, Bonda jest dziennikarką z wykształcenia.

\section{Główne założenie Maszyny do pisania}

Rzecz nosi tytuł: Maszyna do pisania. Kurs kreatywnego pisania, a u jej podstaw stoi ważne założenie: „pisania można się nauczyć”, które zostało skonfrontowane z przeświadczeniem, że „pisanie to wyłącznie dar od Boga”.

Przywołam i skomentuję kilka początkowych fragmentów, żeby uwypuklić ogólną intencję autorki.

\footnotetext{
Można - pisze Bonda we wstępie. - Pisania można się nauczyć, ale, jak mawiała moja babcia: 'Nikomu nie nalejesz oleju do głowy'. Pisarzem się jest lub nie. Wielu moich uczniów ma to 'coś' w sobie. Czasem widać to od pierwszej scenki, którą zadałam na rozgrzewkę, a czasem potrzeba wielomiesięcznego treningu. Tak, pisanie jest jak sport. Nabitą zdaniami rękę czuje się już od pierwszego akapitu. Niektórym wystarczy kilka słów otuchy i konstruktywna krytyka tekstu (nie ma to nic wspólnego z ocenami w szkole). Inni cudownie destruują się w trakcie trwania kursu, bo mało kto wie, że na pisanie trzeba się otworzyćc ${ }^{1}$.
}

Literaturoznawcy bardzo często kwitują „kreatywne pisanie” niechętną frazą: „talentu nie można się nauczyć". Jak widzimy, Bonda to potwierdza, ale równocześnie sugeruje, że stawką jest jednak coś innego: trenowanie talentu.

Sprawdzanie własnych możliwości. Szlifowanie umiejętności, które jeszcze nie miały szansy się uobecnić. Testowanie wiedzy operacyjnej, którą pisarze od wieków wypracowują i ciągle dostosowują do oczekiwań zmieniającej się publiczności.

A to już brzmi całkiem sensownie, powiedziałbym wręcz, że profesjonalnie. Chcąc robić coś rzetelnie, regularnie, $\mathrm{z}$ sukcesem, trzeba się odpowiednio przygotować i stale dbać o formę.

\footnotetext{
${ }^{1}$ K. Bonda, Maszyna do pisania. Kurs kreatywnego pisania, Warszawa 2015, s. 16-17.
} 
Niektóre polskie uniwersytety zmieniają swoje nastawienie do creative writing i zaczynają wprowadzać tego rodzaju kursy do swoich programów nauczania. Przykład: kilka tygodni temu prowadziłem warsztaty pisarskie $\mathrm{w}$ ramach studiów podyplomowych organizowanych przez Uniwersytet Warszawski. Ciekawostka: wśród uczestników były osoby przed debiutem, ale i pisarki z paroma książkami na koncie czy scenarzyści popularnych seriali.

Tak, uczę ludzi pisać. - dodaje Bonda. - Lubię dzielić się swoją wiedzą, pomagać adeptom, wydobywać ich z odmętów grafomanii. Spokojnie, to nie przytyk, gdyż każdy pisarz winien stale uważać, żeby zbytnio nie „odpłynąć” od meritum. Nie piszę za moich podopiecznych, nie redaguję, nie narzucam im swojej percepcji świata. Staram się jedynie - jako akuszerka - pomagać w ich „literackich porodach”. Bo pisanie książek to nie poezja, gdzie pocałunek muzy zapładnia twórcę do napisania wiersza, iluminacja zaś cenniejsza niż warsztat. Pisanie książek to ciężka, także fizyczna, praca $^{2}$.

Wybaczmy pisarce niefortunną uwagę o poezji i wyodrębnijmy te elementy, które sugerują, że „uczenie pisania” to swoisty mentoring - zjawisko w świecie filmu i telewizji normalne, zwyczajne, banalne. Tam każdy scenariusz podlega procesowi zwanemu z angielska "development". Dlaczego praca nad powieścią ma wyglądać inaczej?

Myślę, że my, literaturoznawcy, otoczyliśmy kultem przedmiot swoich badań, i w konsekwencji zamieniliśmy naszą dyscypliną w nadmiernie „celebracyjny” i zarazem zbyt wartościujący dyskurs. Cenę dopiero zaczynamy płacić: coraz mniej ludzi chce studiować literaturoznawstwo, które mimo swojego potencjału okazuje się tak mało pragmatyczne oraz kreatywne.

Na moich kursach praca nad powieścią przypomina twórcze zapładnianie, jakkolwiek dziwnie by to brzmiało, a nie nauczanie zza katedry. - wyjaśnia Bonda. - Resztą musi się zająć autor dzieła. Pisanie to praca. Praca jak każda inna ${ }^{3}$.

Tacy badacze kultury popularnej, jak John Fiske, piszą, że akademicy chętnie wcielają się w żandarmów, którzy rozliczają artystów z ich dokonań, skupiając się głównie na surowej ocenie wartości estetycznych. Według nich to błąd, ponieważ ludzie nie szukają w sztuce, wysmakowanych treści, ale bodźców sprawiających, że opowiadana historia wciągnie ich skutecznie do wnętrza fikcyjnego świata. Zmierzam do tego, że wykładowca literaturoznawstwa, przyjmujący punkt widzenia Bondy, to ktoś w rodzaju coacha, który pomaga swojemu podopiecznemu uczynić planowaną powieść atrakcyjniejszą dla odbiorcy.

To wiązałoby się jednak z przejściem z pozycji inteligenckiego autorytetu na pozycje, nazwijmy to, technologa opowieści. Jaka jest różnica? Ten pierwszy skupia się na wykładaniu, jak należy dane dzieło (już istniejące i najczęściej mające ważne miejsce w historii literatury) zrozumieć, a ten drugi służy radą, jak stworzyć emocjonującą story.

\footnotetext{
2 Tamże, s. 15.

${ }^{3}$ Tamże, s. 19-20.
} 


\section{Ostatni cytat:}

Dzielę się tylko tym, do czego sama doszłam ciężką pracą oraz uczestnicząc w licznych kursach pisarskich, scenopisarskich, treningach zagranicznych i warsztatach dla „opowiadaczy historii” prowadzonych przez znanych tutorów z Polski, Europy Zachodniej i Stanów Zjednoczonych, a także eksperymentując we własnym życiu i ciele. Teraz przekazuję otrzymaną pałeczkę. Otwieram ludziom oczy na sprawy, które dla mnie są już dość oczywiste. Gdybym kiedyś, przed debiutem, miała okazję pójść ze swoim tekstem, pomysłem, czy choćby mglistą ideą do człowieka, który także pisze [...] błogosławiłabym takie kursy „creative writing”, których wciąż jest jak na lekarstwo4.

Oto wymowna specyfikacja wiedzy, którą chce przekazać Bonda w swojej książce.

To wiedza sprawdzona na pisarskim froncie, przegadana $\mathrm{z}$ fachowcami od projektowania story, przećwiczona na czytelnikach.

Owszem, może i oczywista dla akademików, ale dla początkujących twórców bardzo przydatna, bo jak najbardziej praktyczna.

Ten passus uprzytamnia mi jeszcze jedną rzecz, niepokojącą zresztą. Profesjonalna wiedza o budowaniu historii produkowana i dystrybuowana jest poza uniwersyteckimi wydziałami zajmującymi się badaniem literatury.

Dlaczego niepokojąca?

Otóż Bonda podpowiada, że literaturoznawcze zasoby (bogate wszakże, niezmierzone, fascynujące), zoperacjonalizowali z zyskiem przedstawiciele innych branż, tak czy inaczej wykorzystujących moc narracji.

Krótko mówiąc: straciliśmy ważne poletko.

Jeden przykład. Wzięty marketingowiec Paweł Tkaczyk opublikował w zeszłym roku w PWNie książkę Narratologia, podobno dobrze się sprzedającą, która stanowi popularyzatorski wykład o tworzeniu elektryzujących historii. Tak oto literaturoznawczy termin, odsyłający do ważnej dziedziny, został nam sprzątnięty sprzed nosa.

Wiedza, która inspiruje

Książka Bondy podzielona jest na dziewięć części, przy czym większość z nich zawiera zbiór ćwiczeń (niekiedy bardzo wartościowych.)

Pierwsza dotyczy „opowieści” i jest dobrze obmyślonym wstępem do pracy nad powieścią.

Druga to esencja wiedzy na temat konstruowania ciekawego „bohatera”.

${ }^{4}$ Tamże, s. 16. 
Trzecia podpowiada, jak zabrać się za stworzenie „świata przedstawionego”.

Czwarta to wykład o planowaniu „fabuły”, którego celem jest wykreowanie odpowiedniej dramaturgii.

Piąta koncentruje się na technikach narracyjnych.

Szósty stanowi krótki instruktaż w zakresie tworzenia dialogów.

Siódma została zatytułowana Dekalog pisarza i zawiera listę aforyzmów odpowiednio ukierunkowujących najistotniejsze czynności pisarskie.

Ósma wprowadza nas w tajniki redagowania stworzonego tekstu.

Dziewiąta, Na drogę, próbuje w subiektywny i emocjonalny sposób odpowiedzieć na pytanie, na czym polega życie pisarza, a sprowadza się do ugruntowania nas w starym dobrym przekonaniu, że uprawianie literatury sprowadza się do prowadzenia żywota zakonnika. No cóż, szczypta mitologii plemiennej zawsze się przyda.

Jak podsumowałbym zawartość Maszyny do pisania?

Uczony literaturoznawca nie znajdzie tu niczego nowego czy odświeżającego dla siebie, ale też przecież nie dla niego została napisana ta książka (choć wyobrażam sobie, że można by napisać „kurs kreatywnego pisania", który byłby intrygujący dla akademika). Ten, kto jest jej rzeczywistym adresatem, czyli początkujący pisarz, powinien być ukontentowany, powinien czuć się zainspirowany. Według mnie praca Bondy jest tymczasem najsolidniejszą pracą tego typu i można ją śmiało zdefiniować jako podręcznik upowszechniający wiedzę operacyjną na temat konstruowania popularnej story.

Zatrzymam się na chwilę przy pojęciu „inspiracji”.

Otóż wspomniana tu wiedza operacyjna powinna posiadać zupełnie inny charakter niż wiedza akademicka.

O jej wartości wcale nie stanowi oryginalność.

Co zatem?

Chodzi mi o to, że musi ona: 1) trafiać bez problemów do umysłu odbiorcy; 2) być łatwa do wdrożenia; 3) przypominać o najważniejszych regułach i „kejsach”; 4) inspirować do poszukiwań nowych rozwiązań oraz 5) zawierać impuls motywujący, zagrzewający do twórczych działan.

Punkt piąty, może najmniej merytoryczny, jest bardzo ważny!

Marshall McLuhan powiadał: „medium is a massage”, otóż to: skuteczna wiedza musi „masować", oddziaływać na zmysły, bodźcować, drażnić układ nerwowy. 
Blisko jej do „design thinking”, a dość daleko do mądrościowego, pouczającego i silnie wartościującego dyskursu uniwersyteckiego, który jest wyrażony najczęściej w naukowym, szalenie specjalistycznym żargonie.

Pisarz to wojskowy i poeta w jednym - pisze Bonda. - Konglomerat cech obu tych zawodów daje gwarancję ukończenia powieści. A to - zakładam - jest celem czytelnika tej książki. Zapewniam, że jeśli zastosujesz się do mojej rady pisania godzinę dziennie, z czasem sam zaczniesz wydłużać tę przyjemność. Kiedy zobaczysz efekty, to już nie będzie obowiązek. Ja potrafię pisać sześć, osiem, dwanaście, a nawet czternaście godzin dziennie (zwłaszcza kiedy kończę powieść). Pracuję niezależnie od tego, czy mi idzie, czy nie. Rano śniadanie, kawa, praca z przerwą na obiad (jeśli nie zapomnę zjeść). Po południu relaks. Nie wolno ci zaniedbywać kontaktów z ludźmi - to twoja odtrutka na chorobę psychiczną. Nie żartuję. Jeśli będziesz pisarzem, większość życia spędzisz samotnie, pogrążony w alternatywnych światach, które istnieją tylko w twojej wyobraźni. Każdy demiurg musi się odbić od żywego człowieka, wyjść z domu, żyć normalnie, jak inni. Zresztą, skąd masz czerpać wiedzę o psychologii swoich postaci, jak podglądając prawdziwych ludzi? Obserwuj, ucz się, rozwijaj duchowo i fizycznie. [...] Zdradzę ci sekret: dyscyplina. Zapomnij o olśnieniach, inspiracji czy wenie twórczej. Nie istnieją domki na skale z widokami na morze, gdzie ty wraz z ukochanym/ ukochaną siedzisz i piszesz. Bzdura! Poeta +generał = pisarz. I pamiętam: najpierw rzemieślnik, potem artysta. To wszystko ${ }^{5}$.

Kiedy badacz czyta takie fragmenty, krzywi się zapewne. Ale bez tego rodzaju wstawek - zawierających chwytliwe metafory, instrukcje, zaklęcia, odwołania do życia codziennego, a nawet osobistego, frazy pełne emocji - niemożliwy jest efektywny „kurs pisania kreatywnego”.

Z mojego punktu widzenia Bonda i inni fachowcy od tworzenia story są dowodem na to, że literaturoznawstwo powinno poszerzyć ofertę naukowo-dydaktyczną.

Jonathan Culler w swojej zgrabnej Teorii literatury wyszczególnił dwie dziedziny, poetykę i hermeneutykę. Według niego poetyka zajmuje się mechanizmami wytwarzającymi znaczenia, hermeneutyka zaś interpretacją znaczeń odnajdywanych w tekście.

Dodałbym jeszcze jedną dziedzinę: storytelling, który najprościej zdefiniowałbym jako sztukę projektowania angażujących opowieści.

Warto zaznaczyć, że wbrew pozorom storytelling to nie jest dziedzina nowa - przeciwnie, ma niezwykle długą, szlachetną, wręcz wybitną historię. Tyle że uprawiany jest gdzieś na peryferiach.

\section{Storytelling jako dziedzina literaturoznawstwa}

Próbując umieścić storytelling na mapie metodologii badań literackich, musielibyśmy wziąć pod uwagę przede wszystkim fenomenologię reprezentowaną przez „krytykę odbioru” (Stanley Fish, Wolfgang Iser) oraz „estetykę recepcji” reprezentowaną przez „szkołę konstancką” (Hans Robert Jauss). 
Patronem zostałby, rzecz jasna, Arystoteles, ulubieniec scenarzystów, którego Poetyka zainicjowała badania nad teorią odbioru opowieści.

Ważnym punktem odniesienia byłby dorobek McLuhana. Przypomnę tylko hasłowo, że z jego książek wyłania się specyficzna koncepcja historii literatury jako opowieści o ewolucji w zakresie technik angażowania uwagi odbiorców.

Ojcem założycielem trzeba by obwołać Allana Edgara Poego, który stworzył coś w rodzaju doktryny literaturoznawstwa operacyjnego. Myślę o tu o jego Filozofii kompozycji z 1846 roku formułującej tezę, że tworzenie opowieści to równanie matematyczne, którego celem jest wywołanie konkretnego efektu emocjonalnego.

Sam McLuhan tak oto zdefiniował rolę Poego w historii literatury:

W pierwszym okresie wielkiej produkcji masowej towarów rynkowych - w tym literatury - powstała konieczność badania doznań i przeżyć odbiorców - twierdzi autor Galaktyki Gutenberga. - Innymi słowy, trzeba było badać efekt produktu, zanim jeszcze powstał. [...] Edgar Allan Poe pierwszy wypracował uzasadnienie tej najwyższej świadomości procesu poetyckiego i zrozumiał, że zamiast adresować utwór do czytelnika, należy czytelnika wciągnąć do utworu' ${ }^{6}$.

I jeszcze jeden przydatny cytat z książki kanadyjskiego badacza:

Artystyczne kalkulacje oparte na doświadczeniu wyprzedzają zwykle naukę i technikę o pełne pokolenie lub nawet więcej. Znaczenie telegraficznej mozaiki w jej dziennikarskim aspekcie nie umknęło uwadze Edgara Allana Poego. Wynalazł on dwa zadziwiające gatunki literackie - poemat symbolistyczny i powieść detektywistyczną. Obie te formy wymagają od czytelnika zaangażowania na zasadzie 'zrób-to-sam'. Oferując niekompletny obraz lub przebieg akcji, Poe wciągał swoich czytelników w proces tworzenia w sposób, który Baudelaire, Valéry i T.S. Eliot i wielu innych podziwiało i naśladowało. Poe natychmiast wykorzystał elektryczną dynamiczność jako istotę publicznego uczestnictwa w procesie twórczym? ${ }^{7}$.

Pointując, storytelling jako dziedzina literaturoznawstwa zajmowałby się czymś, co Siergiej Eisenstein, radziecki reżyser, ale i wybitnie oryginalny analityk tekstów literackich, nazwał „montażem atrakcji”, montażem atrakcyjnych dla odbiorcy opowieści.

Sukces pisarski Katarzyny Bondy stanowi w tym kontekście poważny argument za.

\footnotetext{
${ }^{6}$ M. McLuhan, Galaktyka Gutenberga. Tworzenie człowieka druku, przeł. A. Wojtasik, wstęp G. Godlewski, Warszawa 2017, s. 297

7 Tenże, Zrozumieć media. Przedłużenia człowieka, Warszawa 2004, s. 414.
} 


\section{SEOWA KLUCZOWE:}

POETYKA

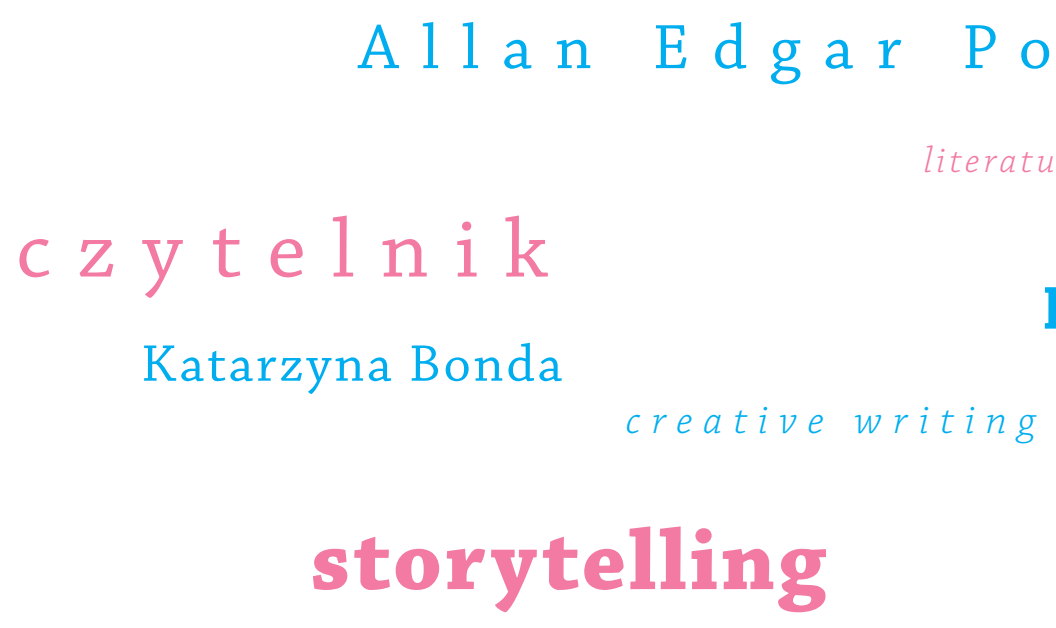

KRYMINAE

EMOCJE

WIEDZA OPERACYJNA

\section{ABSTRAKT:}

Tekst stanowi komentarz do książki Katarzyny Bondy Maszyna do pisania. Kurs kreatywnego pisania. Praca znanej pisarski jest tu przedstawiona jako przykład inspirującego podręcznika z zakresu literaturoznawczej wiedzy operacyjnej skonfrontowanej z typową wiedzą akademicką. Punktem dojścia rozważań jest definicja storytellingu (sztuka projektowania angażujących opowieści) oraz propozycja wyodrębnienia go jako dziedziny literaturoznawczej o bardzo praktycznym i twórczym potencjale.

\section{NOTA O AUTORZE:}

Michał Larek - ur. w 1978 r. Pisarz, literaturoznawca, wykładowca. Pracuje w Instytucie Filologii Polskiej UAM w Poznaniu (Zakład Literatury i Kultury Nowoczesnej). Bada techniki przyciągania uwagi odbiorcy, prowadzi warsztaty ze storytellingu. W 2014 r. wydał Martwe ciała, reportaż o Edmundzie Kolanowskim, seryjnym zabójcy z Poznania, a w 2016 r. powieść kryminalną Mężczyzna w białych butach, inspirowaną autentyczną historią (obydwie książki we współpracy z Waldemarem Ciszakiem, adwokatem). W sierpniu 2017 r. ukazała się Furia, pierwszy tom cyklu kryminalnego zatytułowanego „Dekada”. W 2018 r. ukażą się dwa kolejne, Na tropie oraz Fatum. 